Z Badań nad Książką i Księgozbiorami Historycznymi 2020, t. 14, z. 4

The Studies into the History of the Book and Book Collections 2020, vol. 14, no. 4

www.bookhistory.uw.edu.pl http://doi.org/10.33077/uw.25448730.zbkh

\author{
Katarzyna Setkowicz-Szymanowicz \\ Uniwersytet Wrocławski, Wrocław, Polska \\ katarzyna.setkowicz@uwr.edu.pl
}

iD 0000-0001-5972-7341

\title{
O pożyczaniu książek w Hiszpanii Złotego Wieku
}

\section{On book lending in the Golden Age of Spain}

\begin{abstract}
One of the least investigated aspects of access to literature in sixteenth- and seventeenth-century Spain is the phenomenon of lending and renting books. This is a complex problem not only due to the necessity of co-occurrence of at least two sides of the procedure and the diversity of their motivation, but also the controversy of the act, around which fierce discussions were taking place then. Some of the humanists casted doubt on the purpose of collecting books in libraries if they were not being used to spread knowledge. At the same time, books, although they were still valuable goods, were no longer considered luxurious objects. The act of borrowing (and not paying for them) was seen as a diminution of their value, a testimony of bad reading, which in addition affected the activities of entities related to the book market. Some booksellers tried to adapt to that reality by offering the possibility of renting books for a fee. The documentation of the phenomenon that we have today is rather fragmentary, and the testaments of people who borrowed the book or awaited its return prove to be the richest source of information. In addition, an important source should be the literature of the period, which not only described the phenomenon of borrowing books, but also participated in discussions related to it.
\end{abstract}

Keywords: book lending and borrowing, private libraries, readers, book market, Spain, Golden Age.

Słowa kluczowe: pożyczanie książek, prywatne biblioteki, czytelnicy, rynek książki, Hiszpania, hiszpański Złoty Wiek.

„Z Badań nad Książką i Księgozbiorami Historycznymi” - Udział zagranicznych recenzentów w ocenie publikacji; Stworzenie anglojęzycznej wersji wydawniczej publikacji; Digitalizacja tomów archiwalnych rocznika w celu zapewnienia otwartego dostępu do nich przez Internet oraz wdrożenie i utrzymanie cyfrowej platformy redakcyjnej - zadanie finansowane w ramach umowy nr 653/P-DUN/2019 ze środków Ministra Nauki i Szkolnictwa Wyższego przeznaczonych na działalność upowszechniającą naukę. 
W XVI-wiecznej Hiszpanii, dzięki rozpowszechnieniu się druku książka stała się produktem dostępnym dla znacznej liczby odbiorców. Jej koszt zależał od kilku czynników: od ustalonej odgórnie ceny za składkę (hiszp. tasa) i od liczby tychże; od formatu arkusza; od rodzaju oprawy (to wydatek opcjonalny); od tego, czy była nowa, czy też pochodziła z drugiej ręki. Najpopularniejsze wówczas romanse rycerskie - książki kupowane wyłącznie w celach rozrywkowych - kosztowały między 100 a 200 marawedów, jak dowiadujemy się m.in. $\mathrm{z}$ inwentarza księgarni Juana de Junta w Burgos, sporządzonego w 1556 r. ${ }^{1}$ Jednak w tym samym inwentarzu odnajdujemy również pozycje znacznie mniej kosztowne. Za Złotego osła Apulejusza klient zapłacić musiał 68 marawedów, za Dialektykę Arystotelesa - 85. Za niezwykle popularną Libro áureo de Marco Aurelio, autorstwa jednego z najpoczytniejszych hiszpańskich twórców owego okresu, Antonia de Guevara, zapłacić trzeba było 51 marawedów. W przypadku innych dzieł osiągających rekordowe liczby wydań w wieku XVI, cena kształtowała się jeszcze korzystniej. Deliberación en la causa de los pobres Dominga de Soto to wydatek w wysokości 34 marawedów. Poszukując najbardziej wówczas poczytnego dzieła literatury fikcyjnej, Celestyny Fernanda de Rojas, odnajdujemy wersję w formacie duodecimo za 17 marawedów, oraz w formacie quarto za 25 marawedów. Cárcel de amor w formacie octavo okazuje się wydatkiem rzędu zaledwie 10 marawedów, podobnie jak Comedia llamada selvagia, autorstwa Alonsa de Villegas Selvago, wydana w formacie quarto. Dla porównania warto dodać, że bochenek chleba kosztował wówczas, to jest w połowie XVI w., ok. 2,5 maraweda, a para butów - 57 marawedów ${ }^{2}$.

Pomimo ewidentnego spadku cen w porównaniu do wieku poprzedniego, książki nadal posiadało się, dziedziczyło i przekazywało jako dobra o znacznej wartości $i^{3}$. Zdarzało się, że dana osoba dysponowała odziedziczoną po przodkach biblioteką, z której niewiele jednak korzystała. Posiadanie książek nie stanowiło zatem miarodajnego wyznacznika faktycznej erudycji czy świadomości

1 Inwentarz znajduje się w Archivo Histórico de Protocolos w Burgos, Protocolo de Pedro de Espinosa. Año 1557, k. 100-134v. Dane cytuję za publikacją W. Pettasa, A Sixteenth-Century Spanish Bookstore: The Inventory of Juan de Junta, Philadelphia 1995.

2 Za: C. Griffin, The Crombergers of Seville, Oxford 1988, s. 17.

3 Część bibliofilów obserwowała rozpowszechnienie się druku ze smutkiem, wskazując na znaczny spadek wartości bibliotek. Już w 1519 r. w swoim testamencie humanista i prawnik Gonzalo García de Santa María, pochwaliwszy wpierw w oszczędnych słowach wynalazek druku, ubolewał, że rozpowszechnienie ruchomej czcionki istotnie obniżyło wartość jego biblioteki: „,...) zapisuję mojej żonie wszystko, co znajdzie w moim gabinecie, tak na półkach i pulpitach, jak i na ziemi i wewnątrz skrzyń i skrzynek; książki pergaminowe jak i papierowe, rękopisy i druki, oprawione pergaminem i w innych oprawach, greckie, łacińskie i w romance, o jakiejkolwiek by nie były tematyce; myślę, że warte są dzisiaj, pomimo wynalezienia druku, ponad pięć tysięcy sueldos, a kiedyś, przed drukiem, warte były ponad tysiąc złotych florenów”. Cytat za: M. Serrano y Sanz, Testamento de Gonzalo García de Santa María, „Boletín de la Real Academia Española”, T. I, 1914, s. 470. Wszystkie cytowania pochodzące z wydań obcojęzycznych w thumaczeniu autorki. 
literackiej. Dowodził tego, choć w nieco innym kontekście, wielki hiszpański bibliograf Victor Infantes. Dokonał on próby zbadania biblioteki Fernanda de Rojas pod kątem wpływu lektur pisarza na dzieło, które w wieku XVI stać się miało jednym z największych bestsellerów na terenie Półwyspu Iberyjskiego ${ }^{4}$. Mowa o Celestynie. Tragikomedii o Kaliście i Melibei ${ }^{5}$. Nie ma wątpliwości, że Rojas był człowiekiem niezwykle oczytanym. Jak wykazał jednak Infantes, nie sposób określić genetycznych związków między biblioteką pisarza a Tragikomedia z dwóch powodów: po pierwsze, ewentualne inspiracje literackie dla Celestyny mogły ostatecznie znaleźć się poza biblioteką pisarza (skoro dzieła w niej zlokalizowane w chwili śmierci właściciela nie odnajdywały swojego odzwierciedlenia w historii słynnej rajfurki ${ }^{6}$; po drugie zaś, studiując pośmiertny inwentarz ksiąg pisarza, Infantes odkrył, że część ksiąg (nie wiadomo - które) pozostawiona została u niego jako zastaw za pożyczone pieniądze i nigdy nie odkupiona. W istocie, już pierwsze rozporządzenie testamentu przywołuje bakałarza nazwiskiem Cáceres, któremu oddać należało pewną liczbę ksiąg (bez wskazania tytułów), gdy ten zwróci podjętą za nie sumę w wysokości 12 dukatów. Na marginesie świata literackiego odnajdujemy zatem zupełnie inną funkcję książki, wykorzystywanej jako kapitał nadający się pod zastaw.

Ów margines obejmował również szereg działań mających na celu dotarcie do tekstów poza drogą oficjalną, drogą kupna, z której korzystały osoby lepiej sytuowane. Mniej majętni nabywali książki na pośmiertnych licytacjach, uszkodzone lub ,z drugiej ręki”. Ale istniała również inna droga - wypożyczenie. I tu docieramy do tematu niniejszego artykułu, wprowadzając jednocześnie istotne rozróżnienie, wyrażane przez dwa hiszpańskie czasowniki: prestar oraz alquilar. To pierwsze, rozumiane jako użyczanie bez korzyści osobistych, z przyjaźni lub poczucia obowiązku, to drugie - jako dzierżawienie, wynajmowanie. Obie czynności były sobie przeciwstawiane jeszcze przed epoką druku. Jak pisał czternastowieczny autor Juan Ruiz ${ }^{7}$ w swojej Księdze dobrej miłości: „(...) Jako że jest o dobrej miłości, pożyczaj ją chętnie / nie zmieniaj tytułu, nie spieraj się oń / nie oddawaj za pieniądze ani nie wynajmuj, (...)”.

Aby zrozumieć, jakie emocje rozbudzał wówczas ów temat, musimy zdać sobie sprawę z gorących dyskusji, które krążyły wówczas wokół książki jako

4 V. Infantes, Los libros „traydos y viejos y algunos rotos” que tuvo el Bachiller Fernando de Rojas, nombrado autor de la obra llamada Celestina, „Bulletin Hispanique” 1998, t. 1, s. 7-51.

5 Polskie thumaczenie autorstwa Kazimierza Zawanowskiego.

6 V. Infantes, dz. cyt., s. 51.

7 Juan Ruiz, zwany Arcipreste de Hita (ok. 1283 - ok. 1350), hiszpański poeta i duchowny katolicki. Autor poematu Księga dobrej mitości (Libro de buen amor) 1343 r.

8 J. Ruiz, El libro de Buen Amor, [online] http://www.cervantesvirtual.com/obra-visor/el-libro-de-buen-amor--0/html/ff0ec418-82b1-11df-acc7-002185ce6064_34.html, [dostęp 26.12.2018], strofa 1630. 
przedmiotu i niesionej przezeń wartości. Jeden z kluczowych aspektów książki, przede wszystkim dla jej odbiorców w wiekach XVI i XVII, stanowił paradoks jej podwójnej natury. Materialność przedmiotu była przeciwstawiana jego wymiarowi niematerialnemu, ideowemu i intelektualnemu, a strach przed fizyczną utratą - lękowi przed zapisaniem się niegodnych tekstów w zbiorowej pamięci ${ }^{9}$. To napięcie pomiędzy bytem fizycznym a duchowym od zarania podzieliło odbiorców literatury między tych reprezentujących perspektywę platońską, zgodnie z którą dzieło zawsze wychodzi poza ramy przedmiotu, oraz pragmatyczną, utrzymującą, że bez swego wymiaru materialnego, tekst $\mathrm{w}$ istocie nie istnieje.

$\mathrm{Z}$ owej dychotomii od początku zatem wynikały spory nierozwiązywalne. Książka jako produkt przeznaczony na sprzedaż, do „konsumpcji”, przynależy do rynku towarów i drukowana jest ponieważ stanowi przedmiot, który można sprzedać i kupić, i który zależy od praw popytu i podaży. Jednakże jest to produkt, którego nie konsumuje się tak, jak każdy inny towar. Wyczytywane ze stron słowa nie znikają, nawet, jeśli „zaczytywanie” ksiąg powoduje ich stopniową dezintegrację. Każda lektura powiela zawartość książki w świadomości czytelnika, nie pozostawiając śladów materialnych, lecz mentalne. Nie wszyscy jednak utożsamiali w związku z tym sens istnienia książki z jej realizacją w lekturze.

Ferdynand Kolumb (1488-1539), syn słynnego odkrywcy, podjął się niemożliwego - stworzenia biblioteki uniwersalnej, w której zebrać pragnął wszystkie książki wydane drukiem. W tym celu przeznaczył znaczną część swojego majątku na podróże po świecie i nabywanie kolejnych woluminów, których łącznie zebrał ponad 15 tysięcy. Nie chcąc, by monumentalna biblioteka przestała rosnąć wraz z jego śmiercią, pozostawił znaczną sumę późniejszym opiekunom zbioru, by ci systematycznie go uzupełniali.

Wytyczne dotyczące dzieła jego życia zajmują znaczną część testamentu Kolumba. Szczególną wagę przywiązywał do ochrony zgromadzonych zbiorów, w tym - do środków ostrożności, jakie należało zastosować w przypadku, gdyby ktoś miał ochotę zapoznać się z zawartością którejś z ksiąg:

Gdyby ktoś zechciał przejrzeć albo przeczytać którąś z ksiąg znajdujących się w szafach, niech osoba zajmująca się biblioteką położy rzeczoną księgę na pulpicie, a gdy zostanie już przeczytana, niech odłoży ją na miejsce; a jeśli ktoś skarżyłby się, że w ten sposób nie może zapoznać się z nią tak, jakby sobie tego życzył, niech mu odpowie, że ta biblioteka nie została stworzona, by stać się powszechnym miejscem studiów, lecz by przechowywać księgi; [...] Dlatego też ani depozytariuszowi biblioteki, ani żadnej innej osobie, nie wolno pożyczać ani zezwalać na wyniesienie żadnej księgi, pod karą dziesięciu złotych dukatów

9 Pisze o tym m.in. R. Chartier w Inscrire et effacer. Culture écrite et littérature (XIe-XVIIIe siècle), Paris 2005. 
za każdą brakującą księgę [...]; a gdyby z jego winy straciła biblioteka dziesięć ksiąg, nie tylko za każdą z nich zapłaci dziesięć dukatów, ale jeśli w ciągu dwóch lat nie przywróci brakujących woluminów, straci również zarząd nad całą biblioteką [... $]^{10}$.

Z pewnością Ferdynand Kolumb nie był w stanie przeczytać wszystkich książek zgromadzonych w ogromnej bibliotece. Nie był jednak również skłonny się nimi dzielić. W oczach wielu intelektualistów epoki, taka postawa jawiła się jako karygodna. Ponad 100 lat później napisze Juan de Zabaleta (1610c.a.1670): „Nikt nie może ofiarować czegoś, czego nie posiada, chyba że ma wiele książek, ponieważ pożyczając je, rozpowszechnia wiedzę o rzeczach, o których sam nie wie"11. Zabaleta w swoich kostumbrystycznych ${ }^{12}$ opowiadaniach odmalował postać człowieka, zasługującego na szczególne potępienie - właściciela wielkiej biblioteki, który odmawia pożyczania swoich ksiąg. Pisarz dowodził, że posiadanie wielu książek samo w sobie nie ma większego sensu. Studiując wszak wszystko po trochu, w istocie nie wiemy nic na żaden temat. Jednakże, jak twierdził, jedna chwała przyjść może z posiadania zasobnej biblioteki - możliwość pożyczania woluminów temu, kto pragnie się z nich uczyć. Historycy, lekarze, prawnicy - wszyscy oni potrzebują ksiąg, by móc rozwijać swoją wiedzę i umiejętności, i wszyscy oni odwiedzają domostwo właściciela biblioteki, który każdego zbywa. Jednemu zaś, młodemu adeptowi prawa, którego szczególnie sobie upodobał, proponuje, by zgłębił potrzebną materię na miejscu, na co student oburza się: „,nie było jeszcze takiego, co by studiując w obcym domu dobrze przyswoił zagadnienie"13.

Dziwi się narrator owego literackiego obrazu okrucieństwu właściciela ksiąg, który odmawia pomocy w zdobywaniu wiedzy. Cień zrozumienia pojawiłby się, gdyby tomy były drogie i bogato zdobione. Lecz zdradza nam Zabaleta, że książki w większości zakupione zostały u wędrownego księgarza, wygrzebane z zabłoconego kosza na placu Santa Cruz, a po cenie tak niskiej, że najwięcej kosztowało okrutnika pofatygowanie się po nie. „Czemu, skoro kosztowały tak niewiele, mają tak kosztowne być w utrzymaniu, zwłaszcza że największa korzyść przyszłaby z wypuszczenia ich z rąk?"14. Strach przed utratą ksiąg - ten sam, który w klasztornych bibliotekach każe przybijać je łańcuchami do pulpitów i grozić ekskomuniką potencjalnym złodziejom - sprawia,

10 M. Serrano y Sanz, Proemio, [w:] Hernando Colón, Historia del almirante don Cristóbal Colón, T.I., Madrid 1932, s. CI-CIII.

11 J. de Zabaleta, El día de fiesta en Madrid y sucesos que en él pasan (red. E. Suárez Figaredo), „Lemir Literatura Española Medieval y Renacimiento” 2016, núm. 20, s. 307.

12 Kostumbryzm - nurt w sztuce hiszpańskiej, koncentrujący się na odzwierciedlaniu zwyczajów społeczeństwa z danego regionu (stąd nazwa, od hiszp. costumbre - zwyczaj). Choć kostumbryzm jest łączony przede wszystkim z epoką romantyczną, miał swoich prekursorów już w czasach baroku, np. przywołany w tekście Juan Zabaleta czy Francisco Santos.

13 Tamże, s. 307.

14 Tamże, s. 307. 
że bibliofilowi łatwiej jest wyobrazić sobie, że postaci znikną z wiszących na jego ścianie gobelinów, niż że jakiś wolumin straci miejsce w bibliotece:

Wściekły, że wciąż go proszą o pożyczenie książek, zamyka się wewnątrz biblioteki i zaczyna ściągać z półek tomy o nadniszczonych grzbietach, by zlecić ich nową oprawę. To tak, jakby przechadzał się pośród grobów i owijał zmarłych w nowe całuny: wszak martwymi ciałami są księgi, które stoją jedynie na półkach, a nikomu korzyści nie przynoszą ${ }^{15}$.

Wygłoszone w wieku XVII stanowisko Zabalety nie świadczy jednak o powszechnym wśród przedstawicieli świata literatury przekonaniu. Całkiem przeciwną opinię wyraziła ówczesna mu pisarka María de Zayas (1590-1660), porównując książkę pożyczoną do kobiety lekkich obyczajów, z którą mężczyzna zadaje się w pośpiechu. To niecodzienne porównanie odnajdujemy w prologu do Novelas amorosas y ejemplares. Napisana przez fikcyjną postać, określającą samą siebie jako Desapasionado (tłum. bezstronny), przedmowa stanowi swego rodzaju diatrybę przeciwko tym, co stronią od zakupu książki. Autorka zbioru nowel, donia María de Zayas, przedstawiona zostaje jako pisarka wybitna, a żaden szanujący się czytelnik nie może pozwolić sobie na to, by w jego bibliotece zabrakło jej dzieła. Co więcej, ,nie pożyczonego, lecz zapłaconego; gdyż choćby kosztowało dużo, byłyby to pieniądze dobrze wydane" ${ }^{16}$. Następnie fikcyjny autor prologu przechodzi do złośliwych komentarzy na temat ówczesnego czytelnictwa, wymieniając typy odbiorców literatury, którzy nie konsumują jej w sposób należyty. Są zatem tacy, co, pragnąc zaoszczędzić „tę żałosną kwotę, na którą opiewa cena książki” ${ }^{17}$, żarłocznie „połykają” dzieło za jednym posiedzeniem w księgarni, sądząc, że przebiegnięcie wzrokiem zastąpi dni całe spokojnej lektury. Inni, cieszący się zaufaniem księgarza, pożyczają od niego książki „na próbę”, aby następnie skrytykować je i oddać twierdząc, że nie są warte swojej ceny.

Oczywiście, nie było to zdanie odosobnione w świecie twórców literatury - tych, którzy z książek żyli i których perspektywa „wypożyczania” dzieł straszyła wręcz widmem bankructwa. Najwięksi i najszlachetniejszy czytelnicy, a do takich bez wątpienia należał Alonso Kechana jeszcze przed transformacją w osławionego Don Kichota, wykosztowywali się na ukochane tomy, wyprzedając część swoich majątków. Kwestionowali tym samym fakt, że z książki korzystać można nie posiadając jej na własność, a lektura stanowi faktyczny akt przejęcia własności nad tekstem dzieła, czy to zakupionego, czy też - pożyczonego. Część twórców i przedstawicieli przemysłu księgarskiego, bojkotujących ideę wypożyczania książek, starała się odwrócić tę logikę. Podobnym myśleniem kierowali się Ksiądz z Cyrulikiem, paląc księgi i zamurowując bibliotekę

15 Tamże, s. 308.

16 M. de Zayas y Sotomayor, Novelas amorosas y ejemplares (red. E. Suárez Figaredo), „Lemir Literatura Española Medieval y Renacimiento" 2012, núm. 16, s. 363.

17 Tamże, s. 363. 
samozwańczego rycerza z la Manczy w nadziei, że odcięcie bibliofila od jego ukochanych dzieł wymaże spowodowaną przez nie chorobę. Bez skutku.

Czytanie jest aktem, którego konsekwencje nie wymazują się, a przynajmniej - nie jako efekt celowych działań. Jak pisał Zabaleta, wspomnienie tego, co zostało przeczytane, zostaje zapisane w umyśle, czy, cytując pisarza, „W piersi”: „Częstokroć posiadanie wielu książek służy szerzeniu oszustwa: ci, którzy widzą je na półkach, uważają, że zamieszkały już w piersi właściciela i patrzą na tę pierś z podziwem godnym owej szacownej mądrości"18. Człowiek staje się tym, co wie - wszyscy budujemy w naszych wnętrzach bibliotekę, której nie sposób zburzyć. Powielanie księgi w drukarni to dopiero pierwszy krok. Ta sama księga może być powielana ad infinitum w ludzkich umysłach.

Stąd też innymi oczami powinniśmy spojrzeć na śmieszące nas dziś nierzadko argumenty ówczesnych moralistów, którzy w obawie przed szkodliwym wpływem literatury odradzali zapoznawanie się ze znaczną jej częścią. Wierzyli bowiem, że zawartość książki zostaje w człowieku zaszczepiona. Wymazanie pamięci o złych lekturach to nieosiągalny ideał XVI-wiecznych humanistów, wyrażony wprost przez Gaspara Astete w drugiej połowie XVI w.: ,Jakże miłe Bogu by było, gdyby przyszedł wielki ogień i strawił te księgi i wymazał je z pamięci ludzi"19. Ale idea pojawiała się już wcześniej, jak choćby w (anty) romansie ${ }^{20}$ rycerskim Florisando (1510), w którym mnich Enselmo nakazuje spalenie wszystkich ksiąg spisanych przez magów: Urgandę, Melię i Arkalausa. Wymazuje tym samym z serc i pamięci błędnych rycerzy wspomnienia innych historii i bezbożnych kronik, by mogli rozpocząć walkę z prawdziwym złem, nie pamiętając o grzesznych dokonaniach swych przodków ${ }^{21}$.

Ku zatroskaniu moralistów, księgi, miast płonąć, krążyły w dość nieprzewidywalny sposób pośród krewnych, przyjaciół i znajomych. O takiej rzeczywistości opowiedział nam Miguel de Cervantes, ustami jednego z bohaterów Don Kichota, Samsona Carrasco, odnosząc się do popularności pierwszej części swojego arcydzieła:

Dzieci ją przeglądają, młodzież cytuje, dorośli ją rozumieją, a starzy czczą i w końcu tak jest popularna i tak czytana, znana przez ludzi każdego stanu, że ledwie zobaczą jakąś suchą chabetę, a wołają: „Patrz, Chabetton”. A najbardziej jej lekturze oddają się paziowie, więc

\footnotetext{
18 J. de Zabaleta, dz.cyt., s. 307.
}

19 G. Astete, Quarta parte de las Obras del Padre Gaspar Astete [...] : Del gouierno de la familia y estado de las viudas y donzellas, Burgos: en la imprenta de Philippe de Iunta, 1597, s. 197.

20 Ruy Páez de Ribera, autor Florisando, w istocie dokonuje krytyki gatunku romansu rycerskiego od wewnątrz, występując przeciwko głównym jego filarom: miłości do kobiet i magii. W prologu, Páez de Ribera stwierdza otwarcie, że jego celem jest naprawienie szkody, jaką księgi o Amadisie i Esplandianie „wyrządzają w sercach ludzi prostych i głupich”. R. Páez de Ribera, Florisando, Sevilla: en casa de Juan Varela de Salamanca, 1526, k. Ir.

21 Tamże, k. CCXv. 
nie ma przedpokoju w pańskich domach, gdzie nie znajdziesz Don Kichota, i gdy jedni ją zostawiają, inni biorą, ci o nią wypytują, tamci o nią prosząa 22 .

Do dziś zachowały się liczne dowody owego nieoficjalnego obiegu dzieł, jak na przykład zapisek z inwentarza biblioteki Martí Johana de Galba, który pożyczył niejakiemu bakałarzowi nazwiskiem Torres Gantes ,jedną księgę zatytułowaną Guarino Mesquino”, czy też list Pedra de Acuña do Constanzy de Avellaneda, w którym prosi o Clariana i Morgante z biblioteki hrabiego Gondomara, ponieważ „tutaj nie ma nic do czytania”23. Niektórzy właściciele zasobnych bibliotek pożyczali woluminy na tyle często, że nie mogli obejść się bez prowadzenia szczegółowych rejestrów ksiąg wydanych i zwróconych. Do naszych czasów zachował się rejestr prowadzony przez Juana Vázqueza de Mármol, sewilskiego pisarza i duchownego, pełniącego funkcję korektora w Radzie Kastylii, a następnie kapelana królewskiej kaplicy w Granadzie. Dokumenty o nadanych przez pisarza tytułach: „Libros y papeles que me prestan en Granada de este año 1605-1610" (tłum. Relacja z ksiąg i dokumentów, które pożyczono mi w Granadzie w latach 1605-1610) oraz „Libros y papeles que presto en Granada este año de 1605-1615" (tłum. Relacja z ksiąg i dokumentów, które pożyczyłem w Granadzie w latach 1605-1615) to skrupulatne spisy ksiąg z podziałem na lata, zawierające nazwiska osób, od których książka została pożyczona bądź którzy książkę otrzymali. Po przekazaniu woluminu właścicielowi, zapis wykreślany był z listy ${ }^{24}$.

Jak zapewnia María Trujillo Maza, darowanie i pożyczanie ksiąg było rozpowszechnione w Hiszpanii Złotego Wieku nie tylko ze względu na cenę niektórych egzemplarzy, ale również przez ich znaczenie społeczne - było to poczytywane jako gest przyjaźni, a co najmniej uprzejmości²5. Książki

22 M. de Cervantes, Przemyślny rycerz Don Kichot z Manczy, cz. II, thum. W. Charchalis, Poznań 2016, s. 76.

23 Cyt. za: J. M. Lucía Megías, M. C. Marín Pina, Lectores de libros de caballerías, [online] http://www.cervantesvirtual.com/obra-visor/lectores-de-libros-de-caballerias/html/c01b8049-29a5-49eb-b473-890ed55cbe14_2.html, [dostęp 26.12.2018].

24 J. Vázquez de Marmol, Papeles varios, escritos y recopilados por Juan Vazquez de Marmol (rkps), Biblioteca Nacional de España, sygn. MSS/9226, k. 263r-265r.

25 M. Trujillo Maza, La representación de la lectura femenina en el siglo XVI (praca doktorska), Universitat Autònoma de Barcelona 2009, [online] https://ddd.uab.cat/pub/tesis/2011/ hdl_10803_4907/mctmlde1.pdf [dostęp 27.12.2018], s. 32.

Abstrahujęodzjawiska dzielenia sięksiążkamipośród humanistów w ramachtzw.,Rzeczpospolitej uczonych". Wielu ówczesnych przedstawicieli świata nauki, przynajmniej oficjalnie, uznawało poczucie wspólnoty źródeł wiedzy jako wyznacznik przynależności do określonej grupy, podstawę więzów łączących ich z uczonymi kolegami. Dodawali wówczas do swych znaków własnościowych łacińskie „et amicorum” (pol. „, przyjaciół”). Ten temat, w kontekście ogólnoeuropejskim, poruszali między innymi: Ch. Coppens, Et amicorum: not just for friends, [w:] Syntagmatia: Essays on NeoLatin Literature in Honour of Monique Mund-Dopchie and Gilbert Tournoy, D. Sacré, J. Papy (ed.), Leuven 2009, s. 9-17. Anne Goldgar w odniesieniu do nieco późniejszego okresu pisze o „etyce współpracy" między uczonymi: A. Goldgar, Impolite Learning: Conduct and Community in the 
pożyczano chorym, by umiliły im ciężkie chwile, tak jak uczynił to Diego Sarmiento de Acuña, posyłając swojej matce „,pewną książeczkę po łacinie” z życzeniami szybkiego powrotu do zdrowia ${ }^{26}$. Zadając kłam przekonaniu o powszechnym analfabetyzmie panującym wśród społeczeństwa hiszpańskiego tego okresu, Trevor Dadson potwierdza, że nawet ludzie z najniższych klas społecznych pożyczali i prosili o pożyczenie ksiąg z ,zagadkową wręcz częstotliwością"27.

O praktyce pożyczania książek w Złotym Wieku wiemy dziś jednak przede wszystkim z testamentów. Inwentarz ksiąg był częstą pozycją w testamentach osób dysponujących jakimkolwiek majątkiem ${ }^{28}$. Te zaś podkreślały konieczność dokonania zwrotu ksiąg pożyczonych ich prawowitym właścicielom. Juan Eloy Gelabert González, badając testamenty pochodzące z archiwum szpitala Hospital Real w Santiago de Compostela, odnalazł szereg zapisków odnoszących się do pożyczonych ksiąg. Jak zapewnia, „pośród studentów trudno znaleźć ostatnią wolę, w której nie wspomniano by o cudzych książkach, pozostających w posiadaniu konającego" ${ }^{29}$. Ale obok przykładów obszernych testamentów cytuje również pewną notatkę spisaną na luźnej kartce, zapewne na życzenie ciężko chorego kleryka, który na łożu śmierci pozostawał przejęty niedopełnionym zobowiązaniem:

Potwierdzam, że ja, Juan Coton, kleryk, otrzymałem od Alonsa Lópeza, kleryka, cztery księgi; które to księgi pożyczyłem Alonsowi de Neyra, a nazywają się one: Racional, Postilla, Vita Sanctoro i jeden brewiarz kompostelański ${ }^{30}$.

Nie należy rzecz jasna zakładać, że każdy pożyczający książki brał sobie do serca obowiązek ich zwrotu. Stąd skrupulatne listy pożyczających i niechęć właścicieli bibliotek do tego, by któryś z woluminów opuścił zbiór choćby na chwilę. O takiej sytuacji opowiada nam fragment dzieła Juana Arce de Otálora, Coloquios de Palatino y Pinciano, w którym rozmówcy rozprawiają o szkodliwości romansów rycerskich:

Republic of Letters, 1680-1750, London 1995, s. 12-33.

26 Cytat za: tamże, s. 32.

27 T. Dadson, Libros, lectores y lecturas: estudios sobre bibliotecas particulares españolas del Siglo de Oro, Madrid 1998, s. 40. Kwestia analfabetyzmu jest zresztą poruszana przez wielu badaczy epoki, którzy od dawna postulują rewizję powszechnego przekonania o bardzo ograniczonym dostępie do literatury w wiekach XVI i XVII w Hiszpanii, gdzie większość publikowanych dzieł wydawana była przecież w języku kastylijskim. Zob. m.in.: P. Berger, Libro y lectura en la Valencia del Renacimiento, T. I, Valencia 1987; S. T. Nalle, Literacy and Culture in Early Modern Castile, „Past and Present” 1989, n. 125; B. Bennassar, La España del Siglo de Oro, Barcelona 2001; i in.

28 Dla przykładu w Valladolid, w latach $1530-1599$, 43\% zachowanych inwentarzy post-mortem zawierało wykaz książek posiadanych przez nieboszczyka. Zob. A. Rojo Vega, Libros y bibliotecas en Valladolid (1530-1660), „Bulletin hispanique” 1997, n. 99, s. 196.

29 J. E. Gelabert González, Lectura y escritura en una ciudad del siglo XVI: Santiago de Compostela, En la España Medieval, „Bulletin hispanique” 1982, n.84, s. 272-273.

30 Tamże, s. 272. 
Ja tym bardziej powód mam, by czuć do nich niechęć [do romansów rycerskich, przyp. aut.], ponieważ pożyczyłem jednemu studentowi tom Bartolusa de Saxoferrato aby mógł posłuchać wykładu doktora Peralty, a on wyjechał i zostawił mi go zastawionego na 5 reali za wynajem książek o Amadisach i Esplandianach ${ }^{31}$.

Zaledwie jedno zdanie tak wiele mówi o rzeczywistości książki XVI-wiecznej! Student pożycza podręcznik akademicki, który następnie oddaje w zastaw w zamian za wynajęcie romansów rycerskich. Ta sytuacja nie dziwi jednak jeśli się weźmie pod uwagę, jak wielką popularnością cieszył się ów gatunek, który „uzależniał” od siebie odbiorców, pomimo tego, że była to jedna z najdroższych pozycji w księgarniach i na dodatek nie cieszyła się szczególnym prestiżem. Wynajmowała je nawet, pomimo swej uprzywilejowanej pozycji, Elżbieta de Valois - królowa Hiszpanii, trzecia żona Filipa II. O jej zamiłowaniu do romansów rycerskich dowiadujemy się z dwóch kwitów, których treść, pośród wielu innych interesujących dokumentów, opublikował w aneksie do swojego artykułu Fernando Bouza ${ }^{32}$. W pierwszym z nich, na którym widnieje data kwiecień 1567, nakazuje się niejakiemu panu Paredes wypłacenie zamiataczowi ulic, Pedrowi de Valdivieso, kwoty w wysokości 12 reali $^{33}$ za romanse rycerskie, które wynajęły damy dworu. W drugim zaś, z maja tego samego roku, wspomnianemu już Valdivieso zapłacić należy kolejne 12 reali za romans Cavallero del Febo, którym damy ,zaczytywały się przez jakiś czas”.

Rachunek ów uznać moglibyśmy za anegdotyczny, gdyby nie inne dowody na szczególnie popularny wśród kobiet zwyczaj wynajmowania romansów rycerskich, które odnajdujemy m.in. w słynnej powieści pikarejskiej, Guzmán de Alfarache: „Inne [kobiety, przyp. aut.], nie wytrzymując z ciekawości, przestawały kupować suknie, bo wszystkie pieniądze wydawały na wynajem ksiąg rycerskich" 34 . Ale wynajmowano książki nie tylko od osób prywatnych, które starały się wzbogacić na jednym z niewielu wartościowych przedmiotów, które miały w posiadaniu. Niektórzy księgarze nie poprzestawali na sprzedaży książek, ale, dopasowując się do potrzeb rynku, także świadczyli usługi ich wynajmowania, funkcjonując niemalże niczym ,płatne biblioteki objazdowe" ${ }^{35}$.

31 J. Arce de Otálora, Coloquios de Palatino y Pinciano, T. I, Madrid 1995, s. 459.

32 F. Bouza, Leer en palacio. De «aula gigantium» a museo de reyes sabios, [w:] M.L. López Vidriero, P. M. Cátedra (red.), El libro antiguo español III, Salamanca 1996, s. 41. Oryginały dokumentów znajdują się w Archivo General de Simancas, Casa y Sitios Reales, Leg. 398, k. 759 i 764.

331 real $=34$ marawedy

34 M. Alemán, Segunda parte de la vida de Guzmán de Alfarache, [online] http://www.cervantesvirtual.com/obra-visor/guzman-de-alfarache-segunda-parte--0/html/ff1 a 70ce-82b1-11df-acc7-002185ce6064_4.html\#I_35_[dostęp 28.12.2018].

35 J. Moll, El libro en el Siglo de Oro, „Edad de Oro” 1982, I, s. 49. W przywołanym artykule z 1982 roku, Jaime Moll wskazuje na wynajem książek jako na jedno ze zjawisk, które wymaga zbadania. Dziś wiemy, że braki w zachowanej dokumentacji pozwalają jedynie na fragmentaryczne potraktowanie tematu. 
Niestety, o ile dysponujemy licznymi inwentarzami księgarskimi z epoki, do naszych czasów zachowała się bardzo znikoma liczba hiszpańskich ksiąg rachunkowych ${ }^{36}$, które przekazałyby znacznie więcej informacji na temat sposobów nabywania książek czy też wszelkich opłat związanych z korzystaniem z nich. Na taką dokumentację natknął się jednak Jocelyn Nigel Hillgarth podczas prowadzenia badań nad czytelnictwem na Majorce w latach 1229-1550 ${ }^{37}$. Dzięki księgom rachunkowym niejakiego Tomasa Squera, jedynego księgarza-nakładcy rezydującego w połowie XVI w. na wyspie, dziś poznać możemy cenne dane na temat prawie 20 lat jego działalności (1533-1550) ${ }^{38}$. Pozwalają nam one wyobrazić sobie sposób funkcjonowania niewielkiego, lecz istotnego dla miejscowej ludności zakładu. W swoim sklepie sprzedawał materiały piśmiennicze, ale przede wszystkim książki i inne pomniejsze druki, które, zgodnie z dokumentami, zakupywali tak klienci indywidualni, jak i „hurtowi”, czyli wędrowni księgarze. Dystrybuował przede wszystkim wydania z pras barcelońskich i walencjańskich, a niektóre pozycje wydawane były na jego zlecenie, głównie bardzo popularne tytuły literatury dewocyjnej, np. Siete salmos penitenciales czy La oración de la Emparedada (wpisana niedługo później do indeksu ksiąg zakazanych). Co jednak nas szczególnie interesuje, poza handlem książkami, trudnił się również ich wynajmowaniem, na co wskazują powtarzające się na przestrzeni lat tytuły konkretnych woluminów. Dotze treballs d'Hercules (thum. Dwanaście prac Herkulesa) Enrika de Villena zostało wypożyczone przez trzy różne osoby. Inni wynajmowali książki po kastylijsku, takie jak Dekady Liwiusza lub literaturę o zdecydowanie bardziej rozrywkowym charakterze, jak np. Segunda Celestina niezwykle popularnego Feliciano de Silva. Kobiety, poza zdecydowanie preferowaną fikcją rozrywkową, sięgały również po książeczki nabożne, np. Vida de nostra senyora, wynajęta przez tkaczkę (!) o imieniu Serviana.

Powyższy przegląd zwyczajów związanych z obiegiem książki w Hiszpanii Złotego Wieku dowodzi złożoności problemu dostępu do literatury w owym okresie. Obserwujemy mnogość postaw wobec zjawiska rozpowszechnienia książki oraz sposobów korzystania z niej, często niezależnych od rynku księgarskiego jako takiego. Z konieczności, te zwyczaje muszą być przez to odtwarzane w sposób bardziej złożony niż interpretacja księgarskich archiwów: na podstawie dzieł literackich, testamentów, pół-oficjalnych kwitów czy prywatnych notatek. Pożyczanie i wynajmowanie ksiąg stanowią dotychczas niezbadane kompleksowo zjawiska w odniesieniu do wskazanego okresu.

Kwestię pożyczania książek w Hiszpanii Złotego Wieku rozważać można podług co najmniej trzech punktów odniesienia: osoby pożyczającej; osoby,

36 Problem ten poruszają m.in. Pedro M. Cátedra i Anastasio Rojo, w publikacji Bibliotecas y lecturas de mujeres. Siglo XVI, Madrid 2004, s. 95-96.

37 J.N. Hillgarth, Readers and Books in Majorca 1229-1550, Paris 1991.

38 Tamże. Zawartość ksiąg rachunkowych zamieszczona na s. 831-852. 
która pożycza; oraz pożyczanego dzieła. Warto jednak pamiętać także o zaniepokojeniu przedstawicieli rynku książki, a w szczególności autorów, nakładców i księgarzy, którzy wykazywali największe zainteresowanie tym, by księgi były kupowane. Przed posiadaczem zasobnej biblioteki stała kwestia odpowiedzialności, wynikająca z idei „dzielenia się” wiedzą zawartą w tomach, z którą nierzadko wygrywał jednak strach przed uszczupleniem księgozbioru. Jak się okazuje, mogła również pojawić się idea zarobku, gdy wypożyczanie zmieniało się w wynajmowanie, prestar w alquilar. Osoba, która pożyczała książkę, mogła mieć wątpliwości co do statusu przeczytanego tekstu. Czy ten sposób zapoznawania się z nim jest równie wartościowy jak posiadanie tomu na własność? Tym samym, decyzja o pożyczeniu bądź kupieniu nabierała wymiaru moralnego. Czy sprowadzamy kontakt z książką do przelotnego romansu, jak twierdziła María de Zayas? Czy szkodzimy autorom, zmniejszając zapotrzebowanie na dodruk danego tytułu? A z drugiej strony - jak widzieliśmy, kwestia zwrotu pożyczonego dzieła zaskakująco często stanowiła jedną z głównych bolączek osób na łożu śmierci, co po raz kolejny dowodzi emocjonalnego charakteru relacji tak z właścicielem książki, jak i z książką jako taką.

\section{Bibliografia}

Alemán, M., Segunda parte de la vida de Guzmán de Alfarache, [online] http://www. cervantesvirtual.com/obra-visor/guzman-de-alfarache-segunda-parte--0/html/ffla70ce-82b1-11df-acc7-002185ce6064_4.html\#I_35_.

Arce de Otálora, J., Coloquios de Palatino y Pinciano, T. I, Madrid 1995.

Astete, G., Quarta parte de las Obras del Padre Gaspar Astete [...]: Del gouierno de la familia y estado de las viudas y donzellas, Burgos: en la imprenta de Philippe de Iunta, 1597.

Bouza, F., Leer en palacio. De «aula gigantium» a museo de reyes sabios, [w:] M.L. López Vidriero, P. M. Cátedra (red.), El libro antiguo español III, Salamanca 1996, s. 29-42. Cátedra, P.M., Rojo, A., Bibliotecas y lecturas de mujeres. Siglo XVI, Madrid 2004.

Cervantes y Saavedra, M. de, Przemyślny rycerz Don Kichot z Manczy cz. II, tłum.

W. Charchalis, Poznań 2016, s. 76.

Chartier, R., Inscrire et effacer. Culture écrite et littérature (XIe-XVIIIe siècle), Paris 2005. Coppens, Ch., Et amicorum: not just for friends, [w:] D. Sacré, J. Papy (red.), Syntagmatia: Essays on Neo-Latin Literature in Honour of Monique Mund-Dopchie and Gilbert Tournoy, Leuven 2009, s. 9-17

Dadson, T., Libros, lectores y lecturas: estudios sobre bibliotecas particulares españolas del Siglo de Oro, Madrid 1998.

Gelabert González, J. E., Lectura y escritura en una ciudad del siglo XVI: Santiago de Compostela, „Bulletin hispanique” 1982, n.84, s. 264-290.

Griffin, C., The Crombergers of Seville, Oxford 1988. 
Hillgarth, J.N., Readers and Books in Majorca 1229-1550, Paris 1991.

Infantes, V., Los libros "traydos y viejos y algunos rotos" que tuvo el Bachiller Fernando de Rojas, nombrado autor de la obra llamada Celestina, „Bulletin hispanique” 1998, t. 1, s. 7-51.

Lucía Megías, J.M., Marín Pina, M.C., Lectores de libros de caballerías, [online] http:// www.cervantesvirtual.com/obra-visor/lectores-de-libros-de-caballerias/html/c01b8049-29a5-49eb-b473-890ed55cbe14_2.html.

Moll, J., El libro en el Siglo de Oro, „Edad de Oro” 1982, t. 1, s. 43-54.

Páez de Ribera, R., Florisando, Sevilla: en casa de Juan Varela de Salamanca, 1526.

Pettas, W., A Sixteenth-Century Spanish Bookstore: The Inventory of Juan de Junta, Philadelphia 1995.

Rojo Vega, A., Libros y bibliotecas en Valladolid (1530-1660), „Bulletin hispanique” 1997, t. 99, s. 193-210.

Ruiz, J., El libro de Buen Amor, [online] http://www.cervantesvirtual.com/obra-visor/el-libro-de-buen-amor--0/html/ff0ec418-82b1-11df-acc7-002185ce6064_34.html.

Serrano y Sanz, M., Proemio, [w:] Hernando Colón, Historia del almirante don Cristóbal Colón, t.1, Madrid 1932, s. CI-CIII.

Serrano y Sanz, M., Testamento de Gonzalo García de Santa María, „Boletín de la Real Academia Española” 1914, t. 1, s. 470-478.

Trujillo Maza, M., La representación de la lectura femenina en el siglo XVI (praca doktorska), Universitat Autònoma de Barcelona 2009, [online] https://ddd.uab.cat/pub/ tesis/2011/hdl_10803_4907/mctm1de1.pdf.

Vázquez de Marmol, J., Papeles varios, escritos y recopilados por Juan Vazquez de Marmol (rkps), Biblioteca Nacional de España, sygn. MSS/9226.

Zabaleta, J. de, El día de fiesta en Madrid y sucesos que en él pasan (red. E. Suárez Figaredo), „Lemir Literatura Española Medieval y Renacimiento” 2016, núm. 20, s. 145-344.

Zayas y Sotomayor, M. de, Novelas amorosas y ejemplares (red. E. Suárez Figaredo), „Lemir Literatura Española Medieval y Renacimiento” 2012, n. 16, s. 354-568. 